\title{
Incidence of Helicobacter Pylori Infection in Cases of Hyperemesis Gravidarum
}

\author{
M. Elmahdy ${ }^{1 *}$, Sameh S. Sadek ${ }^{1}$, A. Elmarsafawy ${ }^{1}$, D. Elkafash ${ }^{2}$, Azza Elhenawy ${ }^{1}$ \\ ${ }^{1}$ Department of Obstetrics and Gynecology, Faculty of Medicine, Alexandria University, Alexandria, Egypt \\ ${ }^{2}$ Department of Clinical and Chemical Pathology, Faculty of Medicine, Alexandria University, Alexandria, Egypt \\ Email: *mahdy_moh@yahoo.com
}

How to cite this paper: Elmahdy, M., Sadek, S.S., Elmarsafawy, A., Elkafash, D. and Elhenawy, A. (2017) Incidence of Helicobacter Pylori Infection in Cases of Hyperemesis Gravidarum. Open Journal of Obstetrics and Gynecology, 7, 411-419. https://doi.org/10.4236/ojog.2017.74043

Received: March 3, 2017

Accepted: April 17, 2017

Published: April 20, 2017

Copyright () 2017 by authors and Scientific Research Publishing Inc. This work is licensed under the Creative Commons Attribution International License (CC BY 4.0)

http://creativecommons.org/licenses/by/4.0/

\begin{abstract}
Background: One of the serious problems affecting pregnant females is Hyperemesis gravidarum. Different theories were suggested. But the main etiology is still unknown. Objectives: To determine the incidence of Helicobacter pylori infection in cases of Hyperemesis gravidarum. Patients and methods: Case control study of 80 cases ( 40 cases of Hyperemesis gravidarum (HEG) and 40 cases of normal pregnant females). Determination of Helicobacter pylori antibodies was done in serum and stool for the two studied groups. Results: $75 \%$ of cases of HEG were positive of Helicobacter pylori in stool samples and $37.50 \%$ of normal pregnant females. These results were statistically significant $(\mathrm{P}=0.001)$. The prevalence of $\mathrm{HpIgG} \mathrm{AB}$ and $\mathrm{HpSAB}$ was $77.5 \%$ in the patients group with HEG, and $55.0 \%$ in control studied group ( $\mathrm{P}$ $=0.05)$. There was a significant difference between HEG cases and normal pregnancy as regards serum sodium (0.042). Conclusions: Infection by Helicobacter pylori may be one of the risk factors for HEG. Helicobacter pylori AB in both serum and stool is higher in HEG cases than in normal pregnant females.
\end{abstract}

\section{Keywords \\ HEG, H. pylori, Pregnancy}

\section{Introduction}

Approximately $50 \%$ of pregnant women suffer from nausea and vomiting. And about of $80 \%$ these symptoms begin between the $4^{\text {th }}$ and $7^{\text {th }}$ week after the last menstrual period [1].

On the other side, one of the complications occurring during pregnancy is Hyperemesis gravidarum (HG). Its symptoms include intractable nausea, vomiting, and dehydration and occur in $0.5 \%-2.0 \%$ of pregnant women [2] [3] 
usually in the $1^{\text {st }}$ trimester [4]. In case of severe or inadequately treated Hyperemesis gravidarum, another symptoms maybe appear such as: [2] loss of 5\% or more of pre-pregnancy body weight, dehydration, causing ketosis [4] and metabolic imbalances which may result in metabolic ketoacidosis [2].

The etiology of HG is most likely to be multifactorial. Women with HG are more likely to be younger, primiparous and with female infant sex while body mass index, smoking, socioeconomic status and paternal genes didn't not affect the occurrence of HG [5].

Helicobacter pylori, which is also named Campylobacter pylori, is a gramnegative, microaerophilic bacterium found in the stomach, and may be in other parts of the body, such as the eye [6] [7].

Nashaat et al. suggested that Hyperemesis gravidarum may be caused due to chronic infection with Helicobacter pylori [8]. On the other hand, some researchers failed to assign a relation between the onset and the chronicity of the infection and the occurrence and the severity of HG [9].

Our objectives were to determine the possible relationship between Helicobacter pylori infection and the occurrence of $\mathrm{HG}$ in pregnant women during the first three month of pregnancy.

\section{Materials and Methods}

This study was approved by national research ethics committee and was performed according to the ethical standards shown in the 1964 Declaration of Helsinki and its comparable ethical standards.

Informed consent: "written informed consent was obtained from all women included in the study."

It is a case control study carried out on 80 pregnant females attending the antenatal care clinic of El Shat by Maternity University Hospital in the period from April 2015 till March 2016. They were divided into two studied groups:

Group 1: Forty (50\%) pregnant females complaining of Hyperemesis gravidarum (cases) and group 2: Forty (50\%) normal pregnant females (controls).

Inclusion criteria: all pregnant women included in the study were pregnant with gestational age from 5 to 15 weeks and complaining from symptoms of severe vomiting ( $\geq 3$ times a day) not responding to traditional treatments, weight loss ( $\geq 5 \%$ of body weight); Hyperemesis gravidarum and presence of ketonuria. While the control group were pregnant women with the same gestational age but without manifestation of HG. Both groups in the study were comparable as regards age, obstetric history, and gestational age.

Exclusion criteria: Patients with history of thyroid disorders, multiple pregnancy, psychological diseases, gestational trophoblastic disorders, hepatobiliary disorders and gastric or any intestinal disease.

Women eligible for the study were informed about the nature of the study before blood samples and stool specimens were taken.

Assessment of serum pylori IgG Antibody:

Samples were obtained by venous blood sample and centrifuged at $3000 \mathrm{rpm}$ 
for 10 minutes. Serum was stored at $-30^{\circ} \mathrm{C}$ tillthe analysis. $\mathrm{H}$ pylori IgG antibody (HpIgGAb) was assessed by enzyme-linked immunosorbent assay (ELISA) kits. Results were measured by BioTekELx 800 ELISA reader. Results were assigned as positive, negative, and equivocal. The lower limit for a "positive" result was $\geq 1.00$ and $\leq 0.9$ as a negative test. Values ranging from $0.91-0.99$ was assigned as equivocal.

Determination of $H$ pylori Stool Antigen:

Stool samples from each woman were put into clean cups and stored at $-30^{\circ} \mathrm{C}$ until assessment. All stool samples were assessed for $\mathrm{H}$ pylori stool antigen (HpSA) by HpSA enzyme-linked immunosorbent assay (Diagnostic BioProbessrl, Milano, Italy) according to the manufacturer's manual. Positive result was considered as any value $\geq 0.298$ at optical density of $450 \mathrm{~nm}$ and negative results were $<0.298$.

Statistical analysis of the data:

Statistics and sample size: The number of patients included in the study were chosen from patients admitted to the hospital in the period from April 2015 till March 2016 which is the duration selected for the study. Data were introduced to the computer and processed using IBM SPSS software package version 20.0. Qualitative data were presented using number and percentage. Quantitative data were presented using range (minimum and maximum), mean, standard deviation and median. 5\% level was chosen as Significance for results.

We used the following statistical tests:

1) Chi-square test: in categorical variables

2) Monte Carlo correction: Correction for chi-square when more than $20 \%$ of the cells have expected count less than 5

3) Student t-test: in normally quantitative variables.

4) Z for Mann Whitney test: in abnormally quantitative variables.

\section{Results}

Forty (50\%) pregnant females complaining of Hyperemesis gravidarum (cases) and forty (50\%) normal pregnant females (controls) were enrolled in the study during the period from April 2015 till March 2016. There was no cancelled or dropped cases from the study.

The ages of the women in both groups ranged from 20 to 35 years, they were more or less matched for age; the mean age of patients was $27.50 \pm 4.66$ while that of the controls was $26.95 \pm 4.71$ (Table 1 ).

As regards body weight, it was significantly lower among patients as compared to control group. There was no significant difference between patients and controls according to obstetric history; gravidity, parity and abortion (Table 1).

A significant difference between patient and controls according to vital signs including lower systolic blood pressure and diastolic blood pressure in patients than control group and higher pulse rate pulse in the patients group than the other group (Table 2).

H. pylori stool antigen (HpSA) was $77.5 \%$ (31 of 40 ) in the patients with HEG, 
Table 1. Comparison between the two groups according to demographic data.

\begin{tabular}{|c|c|c|c|c|}
\hline & Cases $(\mathrm{n}=40)$ & Control $(\mathrm{n}=40)$ & $\mathrm{T}$ & $\mathrm{P}$ \\
\hline \multicolumn{5}{|l|}{ Age (years) } \\
\hline Min. - Max. & $20.0-35.0$ & $20.0-35.0$ & & \\
\hline Mean \pm SD. & $27.50 \pm 4.66$ & $26.95 \pm 4.71$ & 0.525 & 0.601 \\
\hline Median & 27.50 & 26.50 & & \\
\hline \multicolumn{5}{|l|}{ Weight (kg) } \\
\hline Min. - Max. & $42.0-74.0$ & $57.0-83.0$ & & \\
\hline Mean \pm SD & $60.40 \pm 10.45$ & $71.70 \pm 7.88$ & $5.461^{*}$ & $<0.001^{*}$ \\
\hline Median & 59.50 & 73.50 & & \\
\hline \multicolumn{5}{|l|}{ Gravidity } \\
\hline Min. - Max. & $1.0-6.0$ & $1.0-6.0$ & & \\
\hline Mean \pm SD & $2.45 \pm 1.36$ & $2.25 \pm 1.39$ & $Z=0.829$ & 0.407 \\
\hline Median & 2.0 & 2.0 & & \\
\hline \multicolumn{5}{|l|}{ Parity } \\
\hline Min. - Max. & $0.0-5.0$ & $0.0-5.0$ & & \\
\hline Mean \pm SD. & $1.25 \pm 1.21$ & $1.10 \pm 1.19$ & $7-0618$ & $0-527$ \\
\hline Median & 1.0 & 1.0 & $2-0.010$ & (0.08 \\
\hline \multicolumn{5}{|l|}{ Abortion } \\
\hline Min. - Max. & $0.0-2.0$ & $0.0-2.0$ & & \\
\hline Mean \pm SD & $0.20 \pm 0.52$ & $0.18 \pm 0.50$ & $Z=0.306$ & 0.760 \\
\hline Median & 0.0 & 0.0 & & \\
\hline
\end{tabular}

t: Student t-test; ${ }^{*}$ : Statistically significant at $\mathrm{P} \leq 0.05 ; \mathrm{Z}: \mathrm{Z}$ for Mann Whitney test.

Table 2. Comparison between the two groups according to vital signs.

\begin{tabular}{ccccc}
\hline & Cases $(\mathrm{n}=40)$ & Control $(\mathrm{n}=40)$ & $\mathrm{T}$ & $\mathrm{P}$ \\
\hline Systolic & & & & \\
Min. - Max. & $80.0-100.0$ & $100.0-130.0$ & & \\
Mean \pm SD. & $89.13 \pm 6.97$ & $116.0 \pm 10.01$ & $13.933^{*}$ & $<0.001^{\star}$ \\
Median & 90.0 & 117.50 & & \\
Diastolic & & & & \\
Min. - Max. & $50.0-75.0$ & $70.0-80.0$ & & \\
Mean \pm SD. & $60.75 \pm 7.81$ & $75.0 \pm 4.53$ & $9.985^{*}$ & \\
Median & 60.0 & 75.0 & & \\
Pulse & & & & \\
Min. - Max. & $75.0-96.0$ & $71.0-84.0$ & & \\
Mean \pm SD. & $86.45 \pm 7.32$ & $76.52 \pm 3.19$ & $7.862^{*}$ & $<0.001^{*}$ \\
Median & 87.50 & 76.0 & & \\
\hline
\end{tabular}

t: Student t-test; ${ }^{*}$ : Statistically significant at $\mathrm{P} \leq 0.05$. 
and $55.0 \%$ (22 of 40$)$ in controls $\left(P=0.05 ; \chi^{2}=4.528\right)$. These results are considered as significant one (Figure 1).

Helicobacter pylori in stool samples were 30 positive of 40 cases with $75 \%$ and 15 positive of 40 controls with $37.50 \%$. These results were statistically significant difference $(\mathrm{P}=0.001)$ (Figure 2$)$.

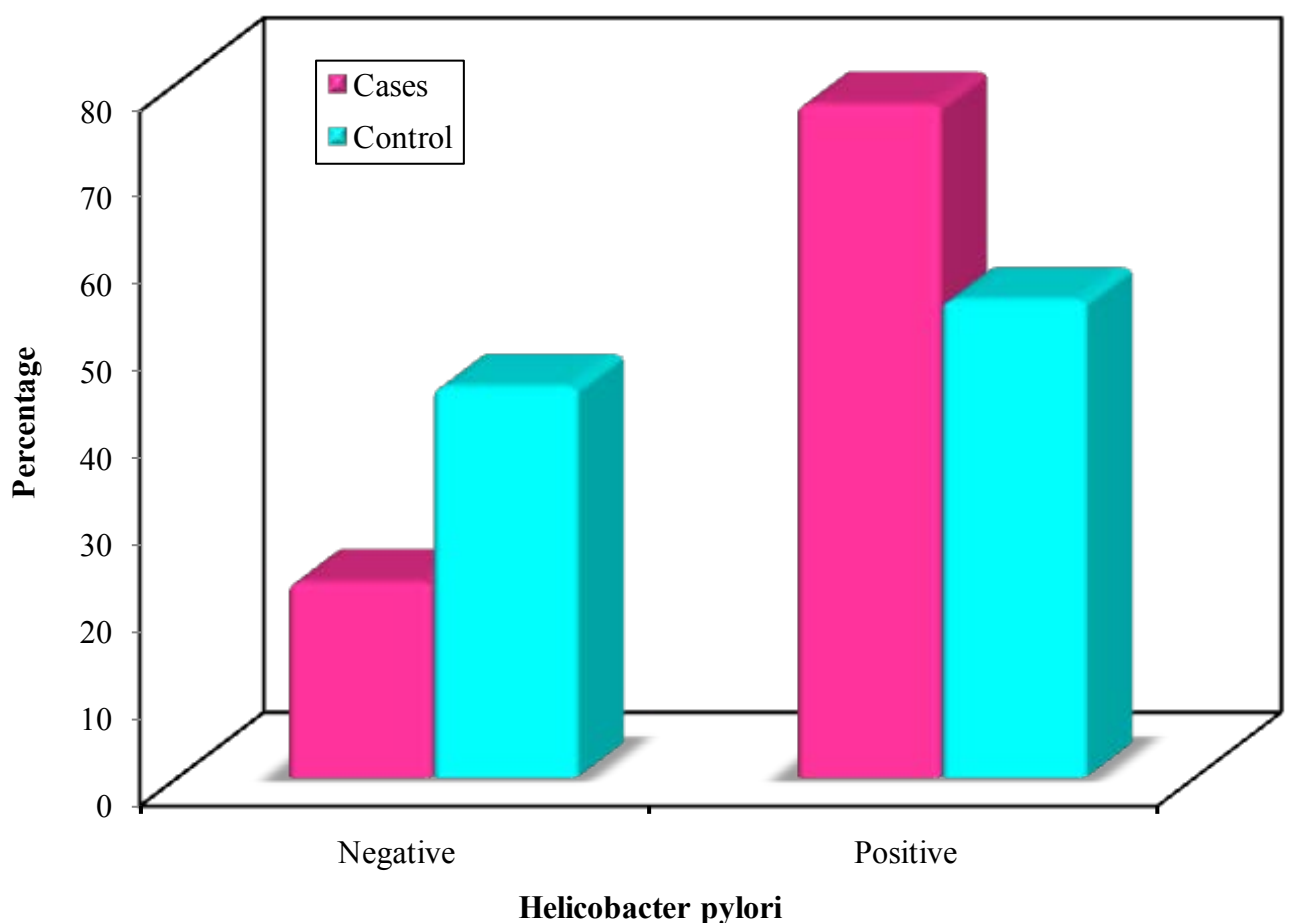

Figure 1. Distribution between the two groups according to Helicobacter pylori seropositivity.

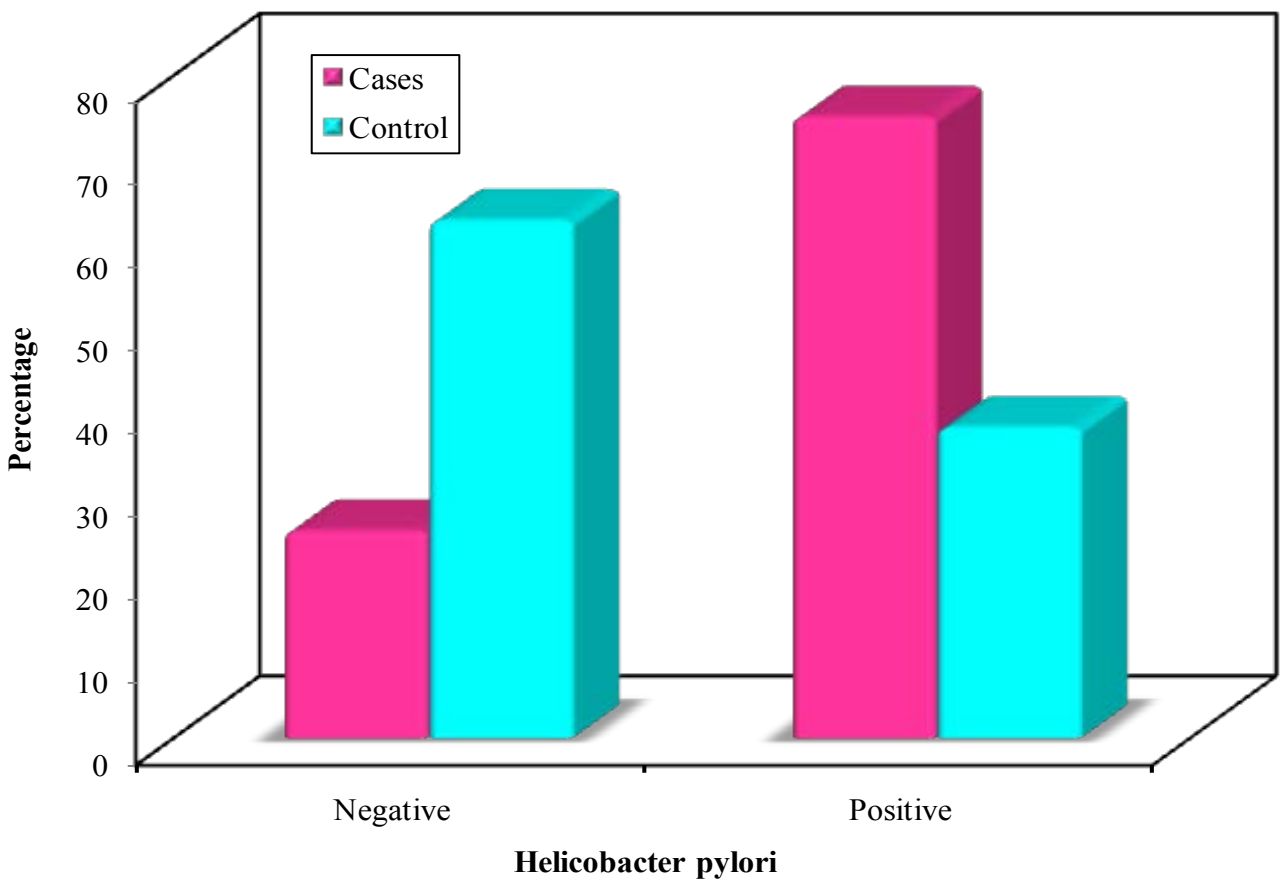

Figure 2. Distribution between the two groups according to Helicobacter pylori testing in stool samples. 
Table 3. Serum sodium, potassium and total serum bilirubin levels in the cases and the control.

\begin{tabular}{|c|c|c|c|c|}
\hline & \multicolumn{2}{|c|}{ HEG } & \multirow{2}{*}{ Test of sig. } & \multirow{2}{*}{$\mathrm{P}$} \\
\hline & Cases $(n=40)$ & Control $(n=40)$ & & \\
\hline \multicolumn{5}{|c|}{ Serum sodium Meq/L } \\
\hline Min. - Max. & $124-139$ & $129-140$ & & \\
\hline Mean \pm SD & $129.6 \pm 6$ & $134 \pm 4.15$ & $\mathrm{t}=0.201$ & $0.042^{*}$ \\
\hline Median & 128 & 131 & & \\
\hline \multicolumn{5}{|c|}{ Serum potassium Meq/L } \\
\hline Min. - Max. & $1.5-4.2$ & $3.6-5.1$ & & \\
\hline Mean \pm SD & $3.2 \pm 1.78$ & $4.61 \pm 1.45$ & $\mathrm{t}=0.306$ & 0.052 \\
\hline Median & 2.0 & 4.0 & & \\
\hline \multicolumn{5}{|c|}{ Serum total bilirubin $\mathrm{mg} / \mathrm{dl}$} \\
\hline Min. - Max. & $0.3-2.0$ & $0.2-1.2$ & & \\
\hline Mean \pm SD & $0.9 \pm 0.48$ & $6 \pm 0.31$ & $\mathrm{t}=0.826$ & 0.409 \\
\hline Median & 1 & 0.7 & & \\
\hline
\end{tabular}

Z: Z for Mann Whitney test; t: Student t-test.

Regarding the prevalence of $H$. Pylori, it didn't differ with age, gravidity and parity in cases with HEG with positive or negative Helicobacter pylori infection.

There was a significant difference between cases with HEG and control groups as regards serum sodium levels while there was no statistical difference as regards serum potassium and serum bilirubin (Table 3 ).

\section{Discussion}

$50 \%$ of pregnant women suffer from Vomiting, and 25\% suffer from nausea. [10] However, only $0.3 \%-1.5 \%$ is the incidence of HEG [11] its cause is theoretical, and one of its reasons is Helicobacter pylori (H. pylori). H. pylori was first discovered in the stomachs of patients with gastritis and ulcers in 1982 [12]. H. pylori is a helix-shaped (classified as a curved rod, not spirochaete) gramnegative microaerophilic bacterium [13].

This study was targeted to determine the relation between $H$. pylori infection and HEG.

The rate of $H$. pylori seropositivity in hyperemetic patients was significantly higher (77.5\%) compared to the control group (55.0\%), $\mathrm{P}=0.058$. Frigo et al. found that $90.5 \%$ of females suffering from HEG were positive for serum $H$. $p y$ lori $\mathrm{AB}$ if compared to $46.5 \%$ of the normal pregnant group [14]. Another study showed that females with $\mathrm{HG}$ had positive serum H. pylori (HP) AB in $92 \%$ of them and it was $45 \%$ in the normal women group [15]. On the other hand two other researchers concluded that there was no correlation between HEG and serum $H$. pylori $\mathrm{AB}$, one conducted in USA [16] and the other done by Berker et al. from Turkey. [17] Also, Shirin Rafie et al. concluded that there was no association between HEG and H.P seropositivity [18]. Golberg D et al. and Irene 
Sandven et al. found that there was a positive relationship between HEG and $H$. pylori seropositivity [19] [20].

Salimi et al. detected Positive serum $H$. pylori IgG antibody in $88.9 \%$ of the patients in the test group vs. $40.7 \%$ of the control group $(\mathrm{P}<0.001)$. Although more patients with HG were seropositive for $H$. pylori infection than control studied group, the correlation between seropositivity for $H$. pylori and the time of onset or duration of HEG symptoms were not able to be demonstrated. Although $H$. pylori infection may be an important factor in causing $\mathrm{HG}$, it may not represent the only cause of the disease [21].

On the other hand Vikanes et al. reported that $H$. pylori exposure was not significantly associated with severe HEG among immigrant women in Norway, By investigating $H$. pylori exposure by IgG seropositivity, VacA and CagA seropositivity or by the detection of $H$. pylori antigens in stool. These results may show a weakness in the association between $H$. pylori and HEG previous expectations, especially in populations with high incidence of $H$. pylori infection [22].

Our results were comparable to the results found in previous studies, and showed that there is an association between HEG and $H$. Pylori infection. $H$. pylori infection is one of the factors that cause GIT disturbance, vomiting, and nausea in general population. But, $H$. Pylori infection determined by the seropositivity for its antibodies is also, prevalent in asymptomatic population as found by Sarker et al. They found the high seroprevalence of vacA- and cagA-positive virulent $H$. pylori strains in an asymptomatic paediatric population indicate that such strains are common in this population and may cause characteristic $H$. $p y$ lori infection in Bangladesh [23]. So, geographical distribution, age, general condition of the female and patient susceptibility may be confounding factors for the associations of $H$. pylori infection with sever HEG cases.

As regards serum electrolytes, there was significantly lower level of sodium in the patients group than the control but this wasn't the same in serum potassium and bilirubin despite of persistent vomiting. This may be due to the rapid correction of potassium by infusion of potassium rich fluids such as ringer's solution or may be due to high potassium level in the diet prescribed to these patients. This may be similar to what was found by Dökmeci $\mathrm{F}$ et al. as he concluded that Hyperemetic women had normal tissue zinc, copper and magnesium concentrations, and rehydration normalized the plasma zinc and copper levels. Otherwise, no significant effects on trace elements were noted [24].

This study showed a risk factor for HEG which is infection by $H$. pylori but the limitations of this study is the limited follow up of the cases and controls as regards pregnancy outcome. Serum electrolytes chlorine and magnesium were not measured in both groups.

\section{Conclusion}

$H$. pylori infection is associated with severe form of HEG and may be listed as one of the risk factors for severe HEG. 


\section{Acknowledgements}

To clinical pathology laboratory team due to their assistance.

\section{Funding}

None.

\section{Conflict of Interest}

There is no conflict of interest.

\section{Ethical Approval}

This article does not contain any studies with human participants or animals performed by any of the authors.

\section{Informed Consent}

Informed consent was obtained from all individual participants included in the study.

\section{References}

[1] Niebyl, J.R. (2010) Nausea and Vomiting in Pregnancy. The New England Journal of Medicine, 363, 1544-1550. https://doi.org/10.1056/NEJMcp1003896

[2] Summers, A. (2012) Emergency Management of Hyperemesis Gravidarum. Emergency Nurse, 20, 24-28. https://doi.org/10.7748/en2012.07.20.4.24.c9206

[3] Goodwin, T.M. (2008) Hyperemesis Gravidarum. Obstetrics and Gynecology Clinics of North America, 35, 401-417. https://doi.org/10.1016/j.ogc.2008.04.002

[4] Ahmed, K.T., Almashhrawi, A.A., Rahman, R.N., Hammoud, G.M. and Ibdah, J.A. (2013) Liver Diseases in Pregnancy: Diseases Unique to Pregnancy. World Journal of Gastroenterology, 19, 7639-7646. https://doi.org/10.3748/wjg.v19.i43.7639

[5] Matthews, D.C. and Syed, A.A. (2011) The Role of TSH Receptor Antibodies in the Management of Graves' Disease. European Journal of Internal Medicine, 22, 213 216. https://doi.org/10.1016/j.ejim.2011.02.006

[6] Giusti, C. (2004) Association of Helicobacter pylori with Central Serous Chorioretinopathy: Hypotheses Regarding Pathogenesis. Medical Hypotheses, 63, 524-527. https://doi.org/10.1016/j.mehy.2004.02.020

[7] Ahnoux-Zabsonre, A., Quaranta, M. and Mauget-Faÿsse, M. (2004) Prévalence de l' Helicobacter pylori dans la choriorétinopathie séreuse centrale et l'épithéliopathie rétinienne diffuse [Prevalence of Helicobacter pylori in Central Serous Chorioretinopathy and Diffuse Retinal Epitheliopathy: A Complementary Study]. Journal Français d Ophtalmologie, 27, 1129-1133. (In French)

[8] Nashaat, E.H. and Mansour, G.M. (2010) Helicobacter pylori and Hyperemesis Gravidarum Continuous Study (2). Natural Science, 8, 22-26.

[9] Sandven, I., Abdelnoor, M., Nesheim, B.I. and Melby, K.K. (2009) Helicobacter pylori Infection and Hyperemesis Gravidarum: A Systemic Review and Meta-Analysis of Case-Control Studies. Acta Obstetricia et Gynecologica Scandinavica, 88, 11901200. https://doi.org/10.3109/00016340903284927

[10] Niebyl, J.R. (2010) Nausea and Vomiting in Pregnancy. The New England Journal of Medicine, 363, 1544-1550. https://doi.org/10.1056/NEJMcp1003896 
[11] Sheehan, P. (2007) Hyperemesis Gravidarum-Assessment and Management. Australian Family Physician, 36, 698-701.

[12] The Nobel Prize in Physiology or Medicine 2005. Retrieved 2 August 2008.

[13] Olson, J.W. and Maier, R.J. (2002) Molecular Hydrogen as an Energy Source for Helicobacter pylori. Science, 298, 1788-1790. https://doi.org/10.1126/science.1077123

[14] Frigo, P., Lang, C., Reisenberger, K., Kolbl, H. and Hirschl, A.M. (1998) Hyperemesis Gravidarum Associated with Helicobacter pylori Seropositivity. Obstetrics \& Gynecology, 91, 615-617. https://doi.org/10.1097/00006250-199804000-00026

[15] Koçak, I., Akcan, Y., Üstün, C., Demirel, C., Cengiz, L. and Yanik, F.F. (1999) Helicobacter pylori Seropositivity in Patients with Hyperemesis Gravidarum. International Journal of Gynecology \& Obstetrics, 66, 251-254. https://doi.org/10.1016/S0020-7292(99)00091-0

[16] Jacobson, G.F., Autry, A.M., Somer-Shely, T.L., Pieper, K.L. and Kirby, R.S. (2003) Helicobacter pylori Seropositivity and Hyperemesis Gravidarum. The Journal of Reproductive Medicine, 48, 578-582.

[17] Berker, B., Soylemez, F., Cengiz, S.D. and Kose, S.K. (2003) Serologic Assay of Helicobacter pylori Infection. Is It Useful in Hyperemesis Gravidarum? The Journal of Reproductive Medicine, 48, 809-812.

[18] Shirazi, L.G. and Tari, S.R. (2015) The Relationship between Helicobacter pylori Infection and Hyperemesis Gravidarum in Pregnant Woman. Tehran University Medical Journal, 73, 182-191.

[19] Golberg, D. (2007) Hyperemesis Gravidarum and Helicobacter pylori Infection: A Systemic Review. Obstetrics \& Gynecology, 110, 695-703. https://doi.org/10.1097/01.aog.0000278571.93861.26

[20] Sandven, I. (2008) Hyperemesis Gravidarum and Helicobacter pylori Infection Epidemiology. European Journal of Epidemiology, 34, 491-498.

[21] Salimi-Khayati, A., Sharami, H., Mansour-Ghanaei, F., Sadri, S. and Fallah, M.S. (2003) Helicobacter pylori Aeropositivity and the Incidence of Hyperemesis Gravidarum. Medical Science Monitor, 9, CR12-CR15.

[22] Vikanes, A.V., Støer, N.C., Gunnes, N., Grjibovski, A.M., Samuelsen, S.O., Magnus, P. and Melby, K.K. (2013) Helicobacter pylori Infection and Severe Hyperemesis Gravidarum among Immigrant Women in Norway: A Case-Control Study. European Journal of Obstetrics \& Gynecology and Reproductive Biology, 167, 41-46. https://doi.org/10.1016/j.ejogrb.2012.11.007

[23] Sarker, S.A., Nahar, S., Rahman, M., Bardhan, P.K., Nair, G.B., Beglinger, C. and Gyr, N. (2004) High Prevalence of cagA and vacA Seropositivity in Asymptomatic Bangladeshi Children with Helicobacter pylori Infection. Acta Paediatrica, 93, 14321436. https://doi.org/10.1111/j.1651-2227.2004.tb02624.x

[24] Dökmeci, F., Engin-Ustün, Y., Ustün, Y., Kavas, G.O. and Kocatürk, P.A. (2004) Trace Element Status in Plasma and Erythrocytes in Hyperemesis Gravidarum. The Journal of Reproductive Medicine, 49, 200-204. 
Submit or recommend next manuscript to SCIRP and we will provide best service for you:

Accepting pre-submission inquiries through Email, Facebook, LinkedIn, Twitter, etc. A wide selection of journals (inclusive of 9 subjects, more than 200 journals)

Providing 24-hour high-quality service

User-friendly online submission system

Fair and swift peer-review system

Efficient typesetting and proofreading procedure

Display of the result of downloads and visits, as well as the number of cited articles Maximum dissemination of your research work

Submit your manuscript at: http://papersubmission.scirp.org/

Or contact ojog@scirp.org 